\title{
High-latitude eruptions cast shadow over the African monsoon and the flow of the Nile
}

\author{
Luke Oman, ${ }^{1}$ Alan Robock, ${ }^{1}$ Georgiy L. Stenchikov, ${ }^{1}$ and Thorvaldur Thordarson ${ }^{2}$ \\ Received 24 July 2006; revised 21 August 2006; accepted 24 August 2006; published 30 September 2006.
}

[1] Nile River records indicate very low flow following the 1783-1784 Laki volcanic eruption, as well as after other high-latitude volcanic eruptions. As shown by climate model simulations of the Laki eruption, significant cooling $\left(-1^{\circ}\right.$ to $-3^{\circ} \mathrm{C}$ ) of the Northern Hemisphere land masses during the boreal summer of 1783 resulted in a strong dynamical effect of weakening the African and Indian monsoon circulations, with precipitation anomalies of -1 to $-3 \mathrm{~mm} /$ day over the Sahel of Africa, thus producing the low Nile flow. Future high-latitude eruptions would significantly impact the food and water supplies in these areas. Using observations of the flow of the Nile River, this new understanding is used to support a date of 939 for the beginning of the eruption of the Eldgjá volcano in Iceland, the largest high-latitude eruption of the past 1500 years. Citation: Oman, L., A. Robock, G. L. Stenchikov, and T. Thordarson (2006), High-latitude eruptions cast shadow over the African monsoon and the flow of the Nile, Geophys. Res. Lett., 33, L18711, doi:10.1029/ 2006 GL027665.

[2] "The inundation of 1783 was not sufficient, great part of the lands therefore could not be sown for want of being watered, and another part was in the same predicament for want of seed. In 1784, the Nile again did not rise to the favorable height, and the dearth immediately became excessive. Soon after the end of November, the famine carried off, at Cairo, nearly as many as the plague; the streets, which before were full of beggars, now afforded not a single one: all had perished or deserted the city" [Volney, 1788 , p. 120]. By January $1785,1 / 6$ of the population of Egypt had either died or left the country in the previous two years [Volney, 1788]. These two years followed the largest high-latitude volcanic eruption in the last 1,000 years, the 1783-1784 Laki eruption in Iceland [Thordarson and Self, 2003].

[3] It has been known for a while that large tropical volcanic eruptions produce a change in atmospheric circulation in the Northern Hemisphere $(\mathrm{NH})$ winter, with a positive phase of the Arctic Oscillation and warming of the NH continents in the first, and sometimes also second, winter following the eruption [Robock, 2000]. Here we show new, strong evidence, from both observations and climate model simulations, that $\mathrm{NH}$ high-latitude eruptions produce changes in atmospheric circulation in the $\mathrm{NH}$ summer following the eruption, weakening the African

\footnotetext{
${ }^{1}$ Department of Environmental Sciences, Rutgers University, New Brunswick, New Jersey, USA.

${ }^{2}$ School of GeoSciences, Grant Institute, University of Edinburgh, Edinburgh, UK.
}

Copyright 2006 by the American Geophysical Union. 0094-8276/06/2006GL027665\$05.00 summer monsoon, reducing precipitation, and reducing the flow in the Nile and Niger Rivers.

[4] During the summer of 1783 much of Western Europe experienced very warm conditions, especially in July [Grattan and Brayshay, 1995; Grattan and Sadler, 1999; Thordarson and Self, 2003; Luterbacher et al., 2004], and the summer was also warm across the Middle East [Stothers, 1999]. This is in contrast to most other areas of the NH which experienced significant negative temperature anomalies, especially over large portions of Asia and North America. Reconstructed summer temperatures using tree ring maximum latewood density data found that 1783 was the coldest summer of the last 400 years in northwestern Alaska [Jacoby et al., 1999]. For tree rings over the Polar Urals and Yamal Peninsula in northwest Siberia, radial growth was the least for 500-600 years [Hantemirov et al., 2004]. Severe drought conditions were noted across India due to a weakened monsoon circulation [Mooley and Pant, 1981]. Similar dry conditions were reported across the Nile River watershed during the summer of 1783 [Hassan, 1998].

[5] An analysis of a Goddard Institute for Space Studies climate model simulation that included volcanic eruptions [Hansen et al., 1988] suggested that tropical volcanic eruptions reduce precipitation over the Sahel region of Africa, and that the 1982 El Chichón eruption was partially responsible for the most severe years of the Sahel drought in 1983 and 1984 [Robock and Liu, 1994]. A more recent climate simulation, using a model that incorporates detailed effects of tropospheric aerosols on clouds and radiation, suggested that the Sahel drought itself, which manifested itself strongly during the period of solar dimming, was caused by the radiative effects of those tropospheric aerosols, reducing the summer temperature contrast between the Sahel and the oceans, and weakening the African monsoon [Rotstayn and Lohmann, 2002]. However, the only previous climate model simulation of the effects of the Laki eruption found no significant temperature effects over Africa in the $\mathrm{NH}$ summer of 1783 and did not comment on changes in the monsoon circulation [Highwood and Stevenson, 2003]. This was probably because they used too small a stratospheric input of $\mathrm{SO}_{2}$ for Laki [Oman et al., 2006], which did not stay in the stratosphere very long.

[6] Here we used the Goddard Institute for Space Studies ModelE general circulation model [Schmidt et al., 2006] with $4^{\circ}$ latitude by $5^{\circ}$ longitude horizontal resolution, to simulate the climate response to the 1783-1784 Laki eruption in Iceland. This particular version has 23 vertical levels up to $80 \mathrm{~km}$. The radiation scheme utilizes correlated $k$-distribution with 15 noncontiguous spectral intervals in the shortwave and 33 intervals in the longwave [Lacis and Oinas, 1991]. Our simulations utilized a q-flux mixed layer ocean, which allows the sea surface temperatures to adjust 


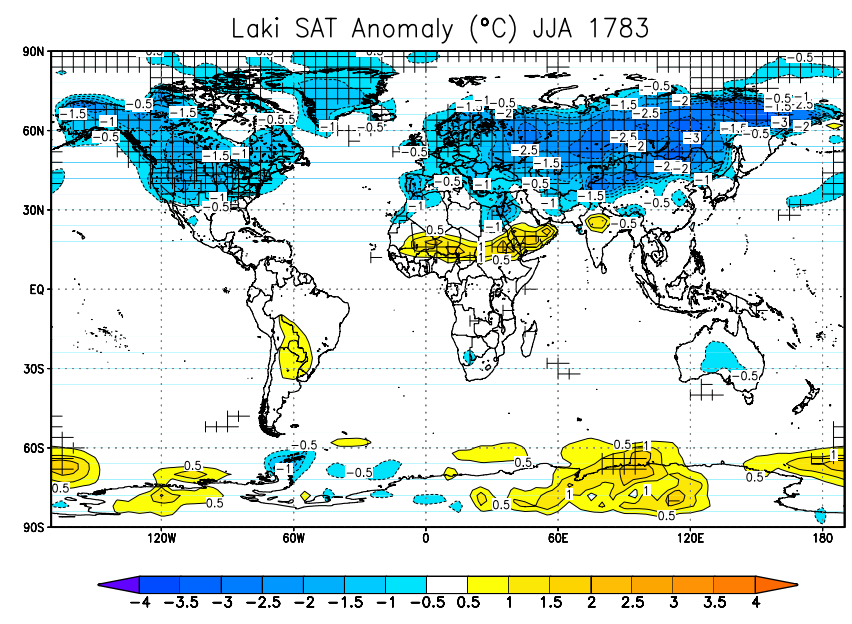

Figure 1. Seasonally averaged surface air temperatures (SAT) anomaly $\left({ }^{\circ} \mathrm{C}\right.$ ) for the summer (JJA 1783) of the Laki eruption. Anomalies are calculated with respect to 30 years of control runs. The hatching corresponds to a $95 \%$ confidence level obtained by a local Student's t test.

to changing atmospheric fluxes. This version also includes a dynamic sea ice model which allows the sea ice to respond to wind.

[7] We conducted 10 ensemble simulations with varying initial conditions to account for weather noise in the system. The control run is based on 30 years of model simulations. Both the control and Laki-forced runs include pre-industrial greenhouse gases and ozone concentrations. The Laki eruptions runs were perturbed with monthly average volcanic sulfate aerosol concentrations calculated previously [Oman et al., 2006] with ModelE coupled to an interactive aerosol model [Koch et al., 2006], based on $\mathrm{SO}_{2}$ emissions into the atmosphere estimated from geological reconstructions [Thordarson et al., 1996].

[8] Figure 1 shows the boreal summer (JJA) surface air temperature response for 1783 . As is typical with strong volcanic eruptions, large negative temperature anomalies occur on land masses under the sulfate aerosol cloud, which acts to reduce incoming solar radiation. This is caused by the backscattering effect of sulfate aerosols and results in cooling of up to $3^{\circ} \mathrm{C}$ over nearly all land masses north of $30^{\circ} \mathrm{N}$. This is consistent with many reports of an unusually cool summer over large parts of Asia and North America [Thordarson and Self, 2003]. Model results indicate $1-2^{\circ} \mathrm{C}$ cooling over Alaska which is significant at the $95 \%$ confidence level and consistent with observations, based on tree ring data, which showed the summer of 1783 to have been the coldest for at least 400 years with anomalies of up to $-4^{\circ} \mathrm{C}$ [Jacoby et al., 1999]. By conducting 10 ensemble members we reduce the effect of natural variability, but also the amplitude of the anomalies. However, some individual runs indicated anomalies of -3 to $-4^{\circ} \mathrm{C}$. The cooling over central Asia in our model simulation of -2 to $-2.5^{\circ} \mathrm{C}$ is also very similar to observations [Jones et al., 2003].

[9] Our model simulations, however, do not reproduce the warm summer reported over Europe, with anomalies of +1 to $+3^{\circ} \mathrm{C}$ for July 1783 [Jones et al., 1985] and +1 to $+1.5^{\circ} \mathrm{C}$ for the 3 month summer average [Luterbacher et al., 2004]. Europe is a very small fraction of the total area of the planet, but there were many people there reporting the climate effects [e.g., de Montredon, 1784; Franklin, 1784]. The summer of 2003 was also unusually warm in Europe, with tragic consequences. At this point, we cannot attribute the warm European summer of 1783 to a specific forcing related to the Laki eruption. This small region of the planet could have been warm due natural variability, like the case of 2003 [Stott et al., 2004].

[10] In contrast to large scale radiative cooling over much of the NH land masses, an area of significant warming of +1 to $+2^{\circ} \mathrm{C}$ resulted in our simulations over the Sahel of Africa, Southern Arabian Peninsula, and across to India (Figure 1). This was caused by a weakening of the Indian and African monsoon circulation due to the decreased temperature gradient between Asia and Europe and the Indian and Atlantic Oceans. Figure 2a shows the cloud cover anomaly during the same period. Significant anomalies of up to $10 \%$ reduction in cloud cover were produced over this same region. This reduction in cloud cover is consistent with precipitation anomalies of -1 to $-3 \mathrm{~mm} /$ day averaged over the 3-month (JJA) period shown in Figure 2b. Some of the

\section{a) Laki Cloud Cover Anomaly (\%) JJA 1783}

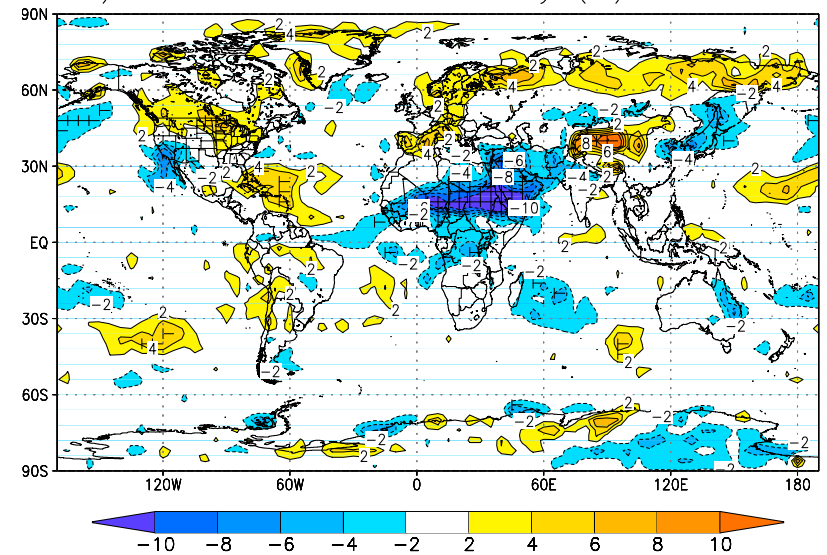

b) Laki Precipitation Anomaly (mm/day) JJA 1783

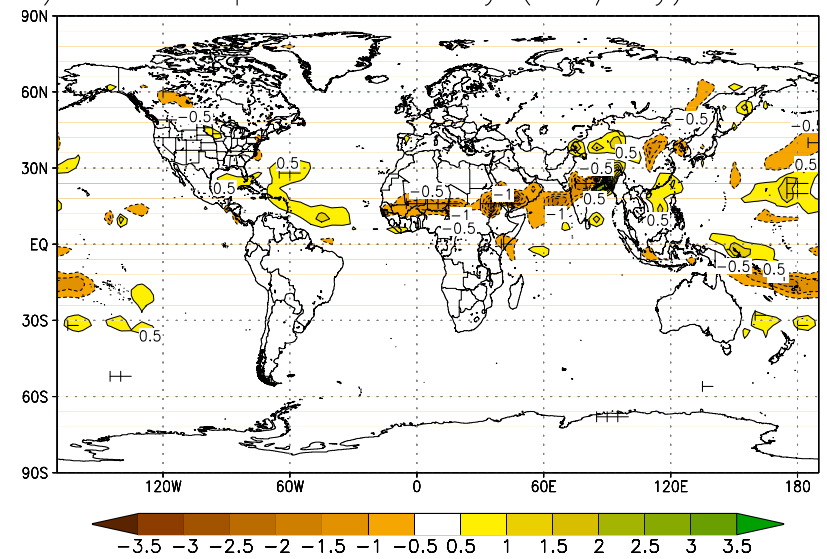

Figure 2. (a) Seasonally averaged anomaly of cloud cover (\%) for the summer (JJA 1783) of the Laki eruption. This is the absolute change in percent cloudiness. (b) Seasonally averaged anomaly of precipitation ( $\mathrm{mm} /$ day) for the summer (JJA 1783) of the Laki eruption. For both plots, anomalies are calculated with respect to 30 years of control runs. The hatching corresponds to a $95 \%$ confidence level obtained by a local Student's t test. 

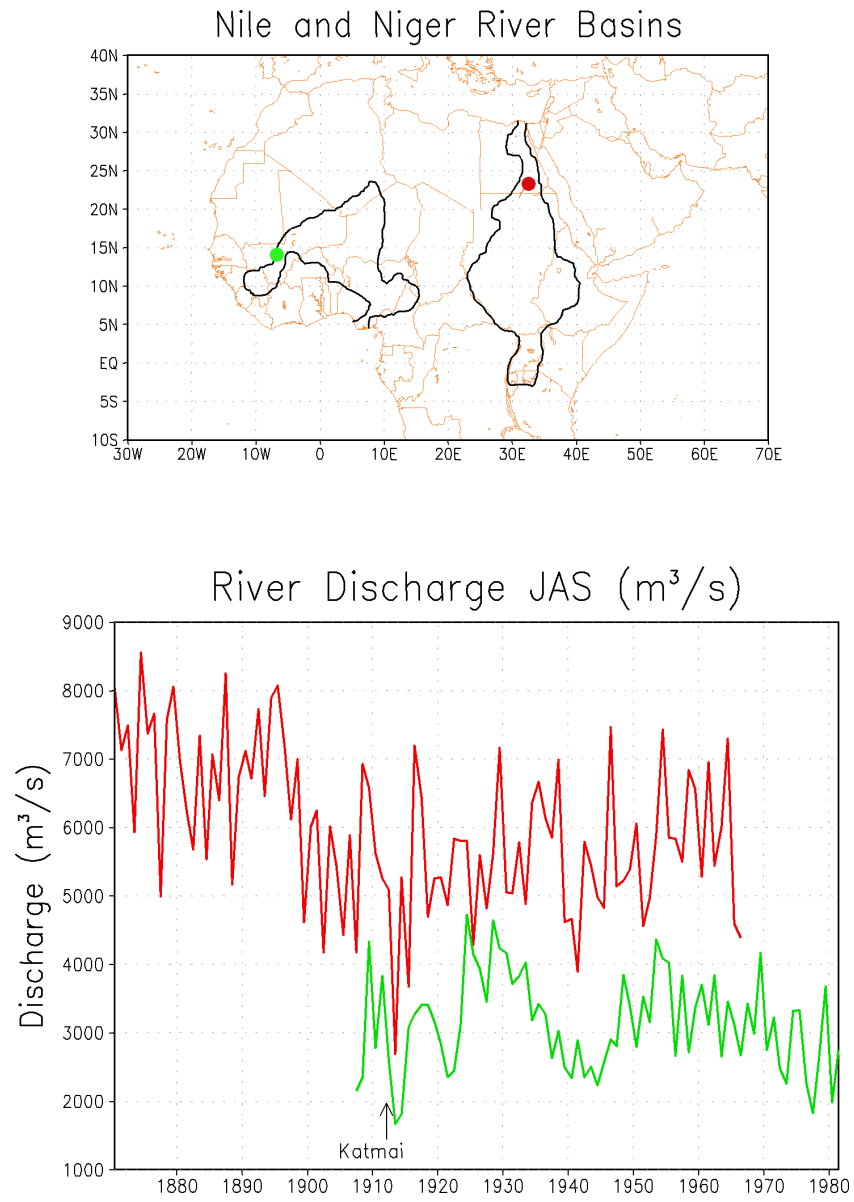

Figure 3. Nile and Niger River basins with the location of the Aswan (red circle) and Koulikoro (green circle) measurement stations. July-August-September (JAS) averaged discharge on the Nile River at Aswan $\left(\mathrm{m}^{3} / \mathrm{s}\right)$ (red line) between 1870 and 1966 and on the Niger River at Koulikoro $\left(\mathrm{m}^{3} / \mathrm{s}\right)$ (green line) between 1907 and 1981 . Also marked is the date of the Katmai eruption. Data from Vorosmarty et al. [1998].

largest anomalies occurred over the Nile and Niger River watersheds, which provide an important supply of water for those living in the surrounding areas. For the Nile River watershed, the total JJA precipitation anomaly is $-42.3 \mathrm{~mm}$, which represents an $18 \%$ reduction for the mean of our 10 ensemble members compared to our 30-year control run. Over the Niger River watershed, the total JJA precipitation anomaly is $-50.6 \mathrm{~mm}$, which is an $11 \%$ reduction from the control run. In addition, the decreased cloud cover and increased temperature over these regions would increase evaporation which would also decrease water available for run-off. 1783 was an extremely low flow year for the Nile River [Hassan, 1998].

[11] Following the 1912 high-latitude Katmai eruption, both the Nile and Niger Rivers had extremely low flow in 1913 (Figure 3). The Aswan High dam was built in the mid 1960s and controlled the discharge after that time on the Nile River, but previous to that, the lowest Nile River discharge of the past 100 years occurred during the summer following the Katmai eruption in 1913 when the flow was only $2692 \mathrm{~m}^{3} / \mathrm{s}$, an anomaly significant above the $99 \%$ confidence level. The only station with measurements going back to the beginning of the 1900s on the Niger River is Koulikoro and it also shows the lowest flow on record in 1913, but it is not as significant as the Aswan data. The station is in the upper portion of the Niger River watershed, so it only integrates precipitation anomalies over that portion of the basin.

[12] To further examine the effect high-latitude eruptions have on rainfall over the Nile river basin we used the very long climate record of the Nile River level, which goes back to 622 A.D. [Kondrashov et al., 2005]. Figure 4 shows 50 -year intervals in the annual high Nile River level surrounding the three largest high-latitude $\mathrm{NH}$ eruptions during the period. In addition to the low flow following the Katmai eruption, very low flow was experienced in 1783 and 1784 following the Laki eruption (middle plot). A lowflow year was also reported in 1782 prior to the Laki eruption. These three years had the lowest river levels of the surrounding 50 years. The significance of the low-flow anomalies following Laki and Katmai are above the 97\% confidence level using 80 years of data surrounding each event, meaning there is less than a $3 \%$ chance that each of
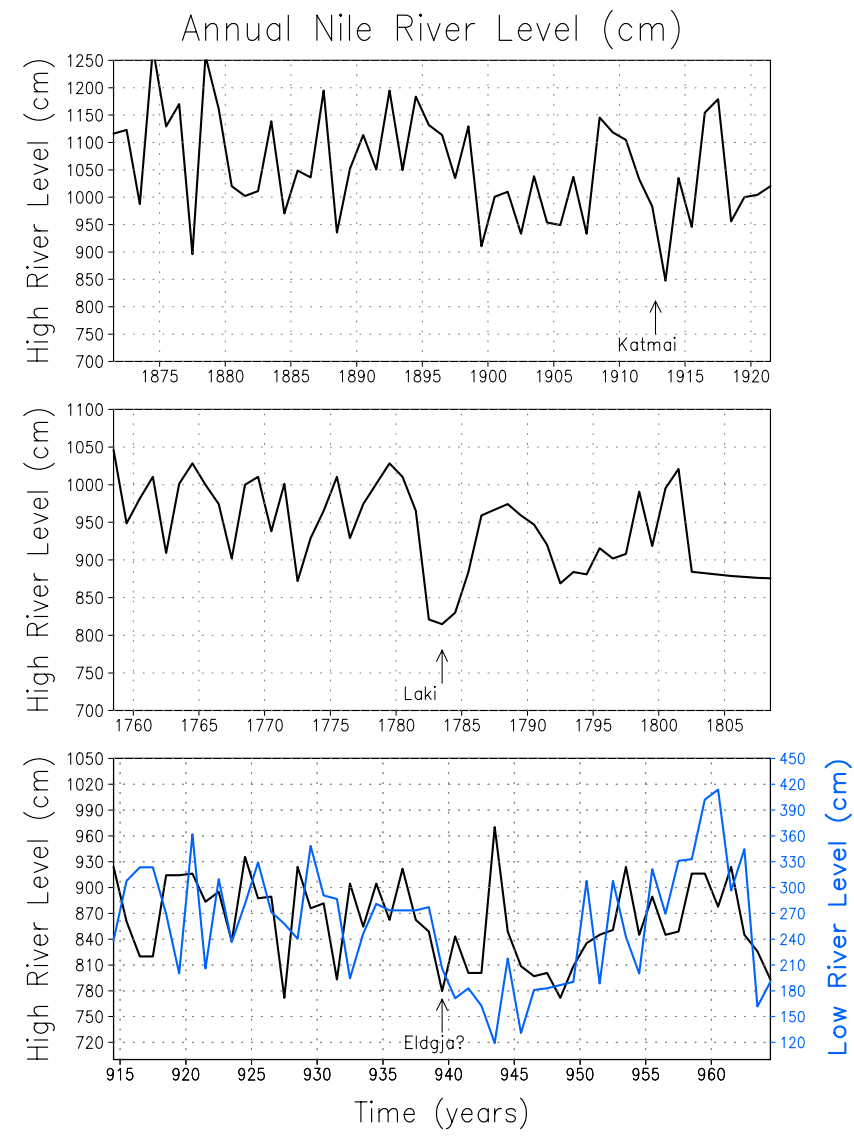

Figure 4. Selected 50-year intervals of annual Nile River level surrounding the three largest high-latitude volcanic eruptions of the past $2000 \mathrm{yr}$. All plots show the high river level for each year, and the bottom plot also shows the low river level. Low river level data are missing for Laki and exhibit a large anthropogenic trend before Katmai. Data from Kondrashov et al. [2005]. 
these anomalies occurred by natural variability within the climate system. Also, the chance that both of these low-flow years following Laki and Katmai are due to natural variability is exceedingly small.

[13] The bottom plot of Figure 4 shows the period of the Eldgjá eruption in Iceland, which we date as beginning in 939 A.D. It is also one of the lowest river levels of that time. The bottom plot shows an even more distinctive low flow beginning in 939. The conventional date for the Eldgjá eruption is $934 \pm 2$ [Simkin and Seibert, 1994; Stothers, 1998; Thordarson et al., 2001], based on ice core data. But once a date is "established," in this case by Hammer et al. [1980] and Hammer [1984], large eruptions are used as markers and some subsequent ice cores are dated to the "known" date, and are thus not independent. Independent GISP2 ice core data date the acidity peak to $938 \pm 4$ [Zielinski et al., 1995], and astronomical observations in Irish annals place the eruption in spring 939 [McCarthy and Breen, 1997]. The winter of 939-940 in western Europe was particularly severe and similar to the harsh winter of 1783-1784 following the Laki eruption [Lamb, 1977; Stothers, 1998]. Thus we conclude that the Eldgjá eruption began in 939 A.D., and not in 934 A.D.

[14] Our results are consistent with an earlier, simpler simulation done to reproduce a high-latitude volcanic eruption by reducing the incoming shortwave radiation north of $50^{\circ} \mathrm{N}$, which resulted in a weakening of the Indian monsoon [Graf, 1992]. More recently, we had found a significant weakening of the Indian monsoon in response to the 1912 Katmai volcanic eruption in Alaska, which resulted from the decreased temperature gradient between Asia and the Indian Ocean [Oman et al., 2005]. But the current work is the first to make the linkage between high-latitude eruptions and the water supply for Sahel and northern Africa, and to document this effect for all the large high-latitude eruptions of the past 2000 years. These results will also allow a prediction of reduction of African water availability following the next large, high-latitude volcanic eruption, allowing society time to plan for and remediate the consequences.

[15] Acknowledgments. We thank D. Koch, D. Shindell, and B. Liepert and two anonymous reviewers for their help and suggestions in this study, and D. Kondrashov and M. Ghil for supplying the Nile River data. This work is supported by NSF grants ATM-0313592, ATM-0313965, and ATM-0351280 and by NOAA grant NA03-OAR-4310155 and NASA grant NNG05GB06G. Model development at GISS is supported by NASA climate modeling grants.

\section{References}

de Montredon, M. M. (1784), Recherches sur l'origine et la nature des vapeurs qui ont régné dans l'atmosphère pendant l'été de $1783, \mathrm{Mem}$. Acad. R., 754-773.

Franklin, B. (1784), Meteorological imaginations and conjectures, Manchester Lit. Philos. Soc. Mem. Proc., 2, 122, (Reprinted in Weatherwise, 35, 262, 1982.)

Graf, H.-F. (1992), Arctic radiation deficit and climate variability, Clim. Dyn., 7, 19-28.

Grattan, J. P., and M. B. Brayshay (1995), An amazing and portentous summer: Environmental and social responses in Britain to the 1783 eruption of an Iceland volcano, Geogr. J., 161, 125-134.

Grattan, J., and J. Sadler (1999), Regional warming of the lower atmosphere in wake of volcanic eruptions: The role of the Laki fissure eruption in the hot summer of 1783, in Volcanoes in the Quaternary, edited by C. R. Firth and W. J. McGuire, Geol. Soc. London Spec. Publ., 161, $161-$ 172.

Hammer, C. U. (1984), Traces of Icelandic eruptions in the Greenland ice sheet, Jokuell, 34, 51-65.
Hammer, C. U., H. B. Clausen, and W. Dansgaard (1980), Greenland ice sheet evidence of post-glacial volcanism and its climatic impact, Nature, 288, 230-235.

Hansen, J., I. Fung, A. Lacis, D. Rind, S. Lebedeff, R. Ruedy, G. Russell, and P. Stone (1988), Global climate changes as forecast by Goddard Institute for Space Studies three-dimensional model, J. Geophys. Res., 93, $9341-9364$.

Hantemirov, R. M., L. A. Gorlanova, and S. G. Shiyatov (2004), Extreme temperature events in summer in northwest Siberia since AD 732 inferred from tree rings, Palaeogeogr. Palaeoclimatol. Palaeoecol., 209, $155-$ 164.

Hassan, F. A. (1998), Climatic change, Nile floods and civilization, Nature Resour., 34, 34-40.

Highwood, E. J., and D. S. Stevenson (2003), Atmospheric impact of the 1783-1784 Laki eruption: Part II Climatic effect of sulphate aerosol, Atmos. Chem. Phys., 3, 1177-1189.

Jacoby, G. C., K. W. Workman, and R. D. D’Arrigo (1999), Laki eruption of 1783, tree rings, and disaster for northwest Alaska Inuit, Quat. Sci. Rev., 18, 1365-1371.

Jones, P. D. et al. (1985), A grid point surface air temperature data set for the Northern Hemisphere, 1851-1984, Tech. Rep. TR022, U.S. Dep. of Energy Carbon Dioxide Res. Div., Washington, D. C.

Jones, P. D., A. Moberg, T. J. Osborn, and K. R. Briffa (2003), Surface climate responses to explosive volcanic eruptions seen in long European temperature records and mid-to-high latitude tree-ring density around the Northern Hemisphere, in Volcanism and the Earth's Atmosphere, Geophys. Monogr. Ser., vol. 139, edited by A. Robock and C. Oppenheimer, pp. 239-254, AGU, Washington, D. C.

Koch, D., G. A. Schmidt, and C. V. Field (2006), Sulfur, sea salt, and radionuclide aerosols in GISS ModelE, J. Geophys. Res., 111, D06206, doi:10.1029/2004JD005550.

Kondrashov, D., Y. Feliks, and M. Ghil (2005), Oscillatory modes of extended Nile River records (A.D. 622-1922), Geophys. Res. Lett., 32, L10702, doi:10.1029/2004GL022156.

Lacis, A., and V. Oinas (1991), A description of the correlated k-distribution method for modeling nongray gaseous absorption, thermal emission, and multiple scattering in vertically inhomogeneous atmospheres, J. Geophys. Res., 96, 9027-9063.

Lamb, H. H. (1977), Climate History and the Future, Princeton Univ. Press, Princeton, N. J.

Luterbacher, J., D. Dietrich, E. Xoplaki, M. Grosjean, and H. Wanner (2004), European seasonal and annual temperature variability, trends, and extremes since 1500, Science, 303, 1499-1503.

McCarthy, D., and A. Breen (1997), An evaluation of astronomical observations in the Irish annals, Vistas Astron., 41, 117-138.

Mooley, D. A., and G. B. Pant (1981), Droughts in India over the last 200 years, their socio-economic impacts and remedial measures for them, in Climate and History: Studies in Past Climates and Their Impact on Man, edited by T. M. L. Wigley, M. J. Ingram, and G. Farmer, pp. 465478, Cambridge Univ. Press, New York.

Oman, L., A. Robock, G. Stenchikov, G. A. Schmidt, and R. Ruedy (2005), Climatic response to high-latitude volcanic eruptions, J. Geophys. Res., 110, D13103, doi:10.1029/2004JD005487.

Oman, L., A. Robock, G. L. Stenchikov, T. Thordarson, D. Koch, D. T. Shindell, and C. Gao (2006), Modeling the distribution of the volcanic aerosol cloud from the 1783-1784 Laki eruption, J. Geophys. Res., 111, D12209, doi:10.1029/2005JD006899.

Robock, A. (2000), Volcanic eruptions and climate, Rev. Geophys., 38, $191-219$.

Robock, A., and Y. Liu (1994), The volcanic signal in Goddard Institute for Space Studies three-dimensional model simulations, J. Clim., 7, 44-55.

Rotstayn, L. D., and U. Lohmann (2002), Tropical rainfall trends and the indirect aerosol effect, J. Clim., 15, 2103-2116.

Schmidt, G. A., et al. (2006), Present day atmospheric simulations using GISS ModelE: comparison to in-situ, satellite and reanalysis data, J. Clim., 19, 153-192, doi:10.1175/JCLI3612.1.

Simkin, T., and L. Siebert (1994), Volcanoes of the World, 2nd ed., 349 pp., Geosci. Press, Tucson, Ariz.

Stott, P. A., D. A. Stone, and M. R. Allen (2004), Human contribution to the European heatwave of 2003, Nature, 432, 610-614.

Stothers, R. B. (1998), Far reach of the tenth century Eldgjá eruption, Iceland, Clim. Change, 39, 715-726.

Stothers, R. B. (1999), Volcanic dry fogs, climate cooling, and plague pandemics in Europe and the Middle East, Clim. Change, 42, 713-723. Thordarson, T., and S. Self (2003), Atmospheric and environmental effects of the 1783-1784 Laki eruption: A review and reassessment, J. Geophys. Res., 108(D1), 4011, doi:10.1029/2001JD002042.

Thordarson, T., S. Self, N. Óskarsson, and T. Hulsebosch (1996), Sulfur, chlorine and fluorine degassing and atmospheric loading by the 17831784 AD Laki (Skaftár Fires) eruption in Iceland, Bull. Volcanol., 58, $205-225$. 
Thordarson, T., D. J. Miller, G. Larsen, S. Self, and H. Sigurdsson (2001), New estimates of sulfur degassing and atmospheric mass-loading by the 934 AD Eldgjá eruption, Iceland, J. Volcanol. Geotherm. Res., 108, 33-54.

Volney, M. C.-F. (1788), Travels Through Syria and Egypt, in the Years 1783, 1784, and 1785, vol. 1, 258 pp., Burnet, White, Byrne, W. Porter, Moore and Dornin, Dublin.

Vorosmarty, C. J., B. M. Fekete, and B. A. Tucker (1998), Global river discharge, 1807-1991, version 1.1 (RivDIS) data set, http://www.daac. ornl.gov/cgi-bin/dataset_lister.pl? $\mathrm{p}=16$, Oak Ridge Natl. Lab. Dist. Active Arch. Cent., Oak Ridge, Tenn.

Zielinski, G. A., M. S. Germani, G. Larsen, M. G. L. Baillie, S. Whitlow, M. S. Twickler, and K. Taylor (1995), Evidence of the Eldgjá (Iceland) eruption in the GISP2 Greenland ice core: Relationship to eruption processes and climatic conditions in the tenth century, Holocene, 5, 129140 .

L. Oman, A. Robock, and G. L. Stenchikov, Department of Environmental Sciences, Rutgers University, 14 College Farm Road, New Brunswick, NJ 08901-8551, USA. (oman@cep.rutgers.edu)

T. Thordarson, School of GeoSciences, Grant Institute, University of Edinburgh, West Mains Road, Edinburgh EH9 3JW, UK. 